\title{
Detection of Messenger Ribonucleic Acid Coding for Glyceraldehyde-3-Phosphate Dehydrogenase in Single Bovine Oocytes and Early Embryos
}

\author{
Takehito Kaneko', Kazuhiro Saeki, 2*, Kazuya Matsumoto', 2, \\ Kayoko Nakagami', Yoshihiko Hosoi1, 2, Hiromi Kato', 2 and \\ Akira Iritani1, 2
}

${ }^{1}$ Department of Genetic Engineering, Kinki University, Wakayama 649-6493 and

${ }^{2}$ Research Institute of Biology-Oriented Science and Technology, Kinki University,

Wakayama 642-0017, Japan

\begin{abstract}
The reverse transcription-polymerase chain reaction (RT-PCR) method is widely used for studying mRNA expression in cells and tissues. In this study, we examined whether the glyceraldehyde-3-phosphate dehydrogenase (G3PDH) gene could be used as an endogenous control for gene expression in single bovine oocytes and early embryos. First, sequencing of partial bovine G3PDH CDNA from ovarian tissue was performed. The sequence analysis of bovine G3PDH CDNA after subcloning indicated a high homology with human, mouse and rat G3PDH cDNA. Next, we examined whether G3PDH could be detected in single bovine oocytes and early embryos by using the RT-PCR method. Signals for G3PDH mRNA were detected in single immature and mature oocytes and single embryos at the one-cell to blastocyst stages. Thus, G3PDH is suitable as an endogenous control for examining mRNA expression even with single bovine oocytes or early embryos by using the RT-PCR method.
\end{abstract}

Key words: Bovine, mRNA, Glyceraldehyde-3-phosphate dehydrogenase, Oocytes, Early embryos.

The reverse transcription-polymerase chain reaction (RT-PCR) is a powerful tool for detecting the mRNA expression of genes. It is commonly used for detecting expression in mammalian gametes and early embryos, since they contain much smaller numbers of cells than other tissues or organs. Several house-keeping genes are often used as endogenous controls for RT-PCR analy-

Received: April 26, 1999

Accepted: May 14, 1999

*To whom correspondence should be addressed. sis. The mRNA for $\beta$-actin has been widely used as a positive control [1], but its expression varies among different tissues [2]. Glyceraldehyde-3-phosphate dehydrogenase (G3PDH) plays a central role in glycolysis and glyconeogenesis [3]. Expression of the G3PDH gene has been detected in various tissues in humans [4], mice [5], rats [6], pigs [2] and chickens [7], but there are few reports on the gene coding of bovine $\mathrm{G} 3 \mathrm{PDH}$ (GenBank accession nos. AJ000039 and U85042). In the present study, we isolate and identify cDNA clones containing part of the coding sequence for bovine G3PDH, and examine whether mRNA expression of the gene can be used as an endogenous control for RT-PCR analysis of gene expression in bovine oocytes and early embryos.

\section{Materials and Methods}

\section{Cloning of partial bovine G3PDH CDNA}

Bovine ovaries were collected from a local slaughterhouse and stored at $-80^{\circ} \mathrm{C}$ until RNA extraction. A piece of the tissue was then homogenized and total RNA was isolated with Trizol (Gibco BRL Life Technologies, Rockville, MD, USA). Briefly, the tissue was homogenized with $5 \mathrm{ml}$ Trizol and $2 \mathrm{ml}$ chloroform, then centrifuged to separate the organic and aqueous phases. RNA was precipitated by adding an identical volume of isopropanol to the aqueous phase. The RNA pellet obtained after centrifugation was washed with $75 \%$ ethanol, then dried before being dissolved in $300 \mu$ DEPC-treated water. Residual DNA in the extracts was removed by digestion with 70 unit/ $\mu$ l Dnase I (Takara Biomedicals, Tokyo, Japan). Reverse transcription was then performed 
at $30^{\circ} \mathrm{C}$ for $10 \mathrm{~min}, 42^{\circ} \mathrm{C}$ for $60 \mathrm{~min}, 99.9^{\circ} \mathrm{C}$ for $6 \mathrm{~min}$, $5^{\circ} \mathrm{C}$ for $5 \mathrm{~min}$ and $4^{\circ} \mathrm{C}$ for $5 \mathrm{~min}$ after the addition of $2 \mu \mathrm{l}$ AMV Reverse Transcriptase XL (Takara), $4 \mu \mathrm{l} 5 \mathrm{x}$ reaction buffer, $8 \mu \mathrm{l}$ dNTP mixture, $2 \mu$ random primer mixture (Takara) and $0.5 \mu \mathrm{l}$ ribonuclease inhibitor (Takara) to $1 \mu \mathrm{l}$ of the RNA extract. After the RT reaction, Rnase $\mathrm{H}$ (Takara) treatment was performed to remove the RNA. The cDNA was then amplified with human G3PDH specific primers, 5'-ACCACAGTCCATGCCATCAC-3' and 5'-TCCACCACCCTGTTGCTGTA-3'. PCR amplification was performed with a mixture of $1 \mu \mathrm{l}$ of cDNA, $0.125 \mu \mathrm{l}$ EX taq polymerase (Takara), $2.5 \mu \mathrm{l} 10 \times$ EX taq buffer (Takara), $2 \mu \mathrm{l}$ dNTP mixture (Takara) and $20 \mu \mathrm{M}$ of each primer. After an initial phase of $5 \mathrm{~min}$ at $94^{\circ} \mathrm{C}, 40$ cycles of amplification were carried out at $94^{\circ} \mathrm{C}$ for 60 seconds, $55^{\circ} \mathrm{C}$ for 60 seconds, and $72^{\circ} \mathrm{C}$ for 60 seconds. A final extension step of $10 \mathrm{~min}$ at $72^{\circ} \mathrm{C}$ ended the reaction. MessengerRNA from human lymphocytes and cumulusgranulosa cells, and mouse ovarian tissues was used as a positive control. The resulting amplification products were separated by $2 \%$ agarose gel electrophoresis and then cloned into the pGEM-T Easy vector (Promega, Madison WI, USA). After analysing 6 plasmid clones with the ALF express DNA sequencer (Pharmacia Biotech $A B$, Uppsala, Sweden), we determined the sequence of partial bovine G3PDH cDNA. Its nucleotide and predicted amino acid sequences were compared and aligned to human (GenBank accession no. M17851), mouse (GenBank accession no. M32599), rat (GenBank accession no. M17701) and previously reported bovine (GenBank accession nos. AJ000039 and U85042) G3PDH cDNA.

\section{Bovine oocyte collection and embryo production}

Bovine in vitro maturation, fertilization and culture were carried out as previously described [8]. Briefly, cumulus-oocytes complexes (COCs) were collected from the small antral follicles (ø 5 to $10 \mathrm{~mm}$ ) of bovine slaughterhouse ovaries. Some of the COCs were vortexed to remove the cumulus and corona cells surrounding the oocytes, and the denuded oocytes, which were regarded as being immature oocytes, were collected and stored at $-80^{\circ} \mathrm{C}$ until RNA extraction. The remainding COCs were matured in TCM-199 (with Earle's salts and 25 $\mathrm{mM}$ HEPES-buffer, Gibco) supplemented with $1 \mathrm{mg} / \mathrm{ml}$ polyvinyl alcohol (cold water soluble, Sigma Chemical Co., St. Louis, MO, USA), $0.5 \mathrm{mM}$ sodium pyruvate, $0.02 \mathrm{AU} / \mathrm{ml}$ follicle stimulating hormone (Antrin, Denka Seiyaku, Tokyo, Japan) and $1 \mu \mathrm{g} / \mathrm{ml}$ estradiol- $17 \beta$ (Sigma) for 21 hours at $39^{\circ} \mathrm{C}$ under $5 \% \mathrm{CO}_{2}$ in air with high humidity. Some of the matured COCs were then vortexed to remove the cumulus and corona cells surrounding the oocytes, and the denuded oocytes with the first polar body, which were regarded as being mature oocytes, were collected and stored at $-80^{\circ} \mathrm{C}$ until RNA extraction. The remainding COCs were fertilized with Percoll-washed bovine spermatozoa [9] in modified defined medium containing $1 \mu \mathrm{g} / \mathrm{ml}$ heparin for 18 hours at $39^{\circ} \mathrm{C}$ under $5 \% \mathrm{CO}_{2}$ in air with high humidity [8]. Following fertilization, cumulus cells and attached spermatozoa were removed from the embryos by vortex agitation. The embryos were cultured to the blastocyst stage in modified synthetic oviduct fluid medium [10] for 168 hours at $39^{\circ} \mathrm{C}$ under $5 \% \mathrm{CO}_{2}, 5 \% \mathrm{O}_{2}$ and $90 \% \mathrm{~N}_{2}$ with high humidity [11]. Single embryos were collected at $24,48,72,96,120,144$ and 168 hours post insemination (hpi), and then stored at $-80^{\circ} \mathrm{C}$ until RNA extraction. The developmental stages of embryos at each hpi were 1-cell, 2-cell, 8-cell, 8- to 16-cell, 16- to 32-cell, morula and blastocyst stages, respectively.

\section{$R T-P C R$ analysis in bovine oocytes/embryos}

Messenger RNA extracted from bovine oocytes and embryos was reverse-transcribed and then the cDNA was amplified by means of a Superscript One-step PCR (Gibco) according to the manufacturer's protocol. PCR for bovine G3PDH was performed with the same primers as described previously. To confirm that the RNA extract did not contain residual genomic DNA, the PCR of the extracts was done without the $R T$ reaction. Both RT-PCR and PCR

\section{M1 P N HL HG MO BO M2}

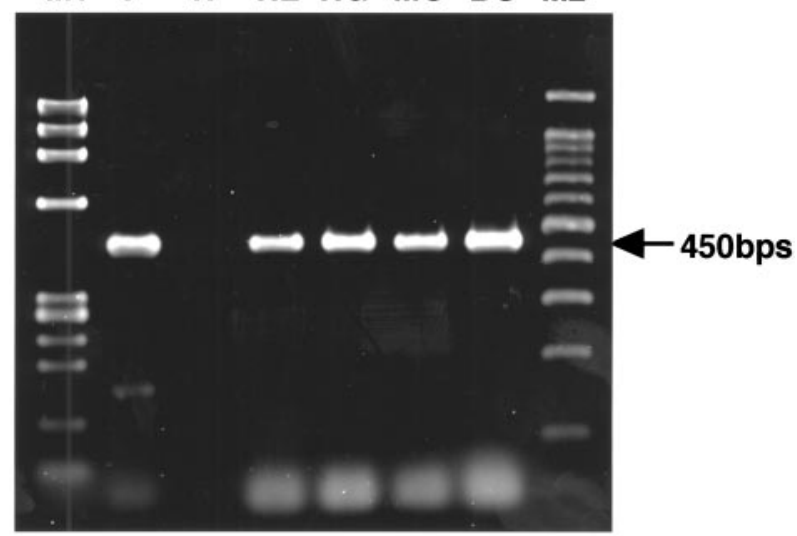

Fig. 1. Detection of G3PDH mRNA in bovine ovarian tissue. M1, molecular marker (øX174-Hae III digest); $\mathrm{P}$, positive control (control cDNA); $\mathrm{N}$, negative control (distilled water); HL, human lymphocytes; HG, human granulosa cells; $\mathrm{MO}$, mouse ovarian tissue; $\mathrm{BO}$, bovine ovarian tissue; $\mathrm{M} 2$, molecular marker (100 bp DNA ladder). 
amplification products were separated by $2 \%$ agarose gel electrophoresis. Experiments were repeated three times.

\section{Results}

\section{Sequence of partial bovine G3PDH cDNA}

Agarose gel electrophoresis of RT-PCR products from bovine ovarian tissue total RNA displayed positive signals of similar size (approximately $450 \mathrm{bp}$ ) to those of human lymphocytes and cumulus-granulosa cells, and mouse ovarian tissues (Fig. 1). As shown in Figs. 2 and 3, the partial cDNA was 452 bp and encoded 150 amino acids. The $452 \mathrm{bp}$ of the non-primer sequence were $83.2 \%$ identical and the corresponding 150 amino

\begin{tabular}{|c|c|c|c|c|c|c|c|c|}
\hline & & & 10 & 20 & 30 & 40 & 50 & \\
\hline bovine & G3PDH & 1 & accacagtcc & atgccatcac & tgccacccag & aagactgtgg & atggeccetc & 50 \\
\hline human & G3PDH & 1 & accacagtcc & atgccatcac & tgccacccag & aagactgtgg & atggeccetc & 50 \\
\hline mouse & G3PDH & 1 & accacagtcc & atgccatcac & tgccacccag & aagactgtgg & atggeccetc & 0 \\
\hline \multirow[t]{2}{*}{ rat } & G3PDH & 1 & accacagtcc & atgccatcac & tgccactcag & aagactgtgg & atggeccetc & 50 \\
\hline & & & 60 & 70 & 80 & 90 & 100 & \\
\hline bovine & G3PDH & 51 & cgggaagctg & tggcgtgacg & gccgaggggc & tgcccagaat & atcatccctg & 100 \\
\hline human & G3PDH & 51 & cgggaaactg & tggcgtgatg & gccgcggggc & tctccagaac & atcatccctg & 100 \\
\hline mouse & G3PDH & 51 & tggaaagctg & tggcgtgatg & gccgtggggc & tgcccagaac & atcatccetg & 100 \\
\hline \multirow[t]{2}{*}{ rat } & G3PDH & 51 & tggaaagctg & tggcgtgatg & gccgtggggc & agcccagaac & atcatccctg & 100 \\
\hline & & & 110 & 120 & 130 & 140 & 150 & \\
\hline bovine & G3PDH & 101 & cttctactgg & cgctgccaag & gccgtgggca & aggtcatccc & tgagctcaac & 150 \\
\hline human & G3PDH & 101 & cctctactgg & cgctgccaag & gctgtgggca & aggtcatccc & tgagctagac & 150 \\
\hline mouse & G3PDH & 101 & catccactgg & tgctgccaag & gctgtgggca & aggtcatccc & agagctgaac & 150 \\
\hline \multirow[t]{2}{*}{ rat } & G3PDH & 101 & catccactgg & tgctgccaag & gctgtgggca & aggtcatccc & agagctgaac & 150 \\
\hline & & & 160 & 170 & 180 & 190 & 200 & \\
\hline bovine & G3PDH & 151 & gggaagctca & ctggcatggc & cttccgcgtc & cccactccca & acgtgtctgt & 200 \\
\hline hum & G3PDH & 151 & gggaagctca & ctggcatggc & cttccgtgtc & cccactgcca & acgtgtcagt & 200 \\
\hline mouse & G3PDH & 151 & gggaagctca & ctggcatggc & cttcogtgtt & cctaccecca & atgtgtccgt & 200 \\
\hline \multirow[t]{2}{*}{ rat } & G3PDH & 151 & gggaagctca & ctggcatggc & cttccgtgtt & cetaccecca & atgtatccgt & 200 \\
\hline & & & 210 & 220 & 230 & 240 & 0 & \\
\hline bovine & G3PDH & 201 & tgtggatctg & acctgccgcc & tggagaaacc & tgccaagtat & gatgagatca & 250 \\
\hline hum & DH & 201 & ggtggacctg & acctgccgtc & tagaaaaacc & tgccaaatat & gatgacatca & 250 \\
\hline mouse & G3PDH & 201 & cgtggatctg & acgtgcegcc & tggagaaacc & tgccaagtat & gatgacatca & \\
\hline \multirow[t]{2}{*}{ rat } & G3PDH & 201 & tgtggatctg & acatgccgcc & tggagaaacc & tgccaagtat & catca & 250 \\
\hline & & & 260 & 270 & 280 & 290 & 300 & \\
\hline bovine & G3PDH & 251 & agaaggtggt & gaagcaggcg & tcagagggcc & ctctcaaggg & cattctaggc & 300 \\
\hline human & G3PDH & 251 & agaaggtggt & gaagcaggcg & tcggagggcc & ccctcaaagg & catcctgggc & 300 \\
\hline mouse & G3PDH & 251 & agaaggtggt & gaagcaggca & tctgagggcc & cactgaaggg & catcttgggc & 300 \\
\hline \multirow[t]{2}{*}{ rat } & G3PDH & 251 & aaggtggt & caggcg & 7ववcc & aaggg & वqवc & 300 \\
\hline & & & 310 & 320 & 330 & 340 & 350 & \\
\hline bovine & G3PDH & 301 & tacactgagg & accaggttgt & ctcctgcgac & ttcaacagcg & acactcactc & 350 \\
\hline hur & G3PDH & 301 & cactgagc & accaggtggt & ctcctctgac & ttcaacagcg & acacccactc & 350 \\
\hline mouse & G3PDH & 301 & actgagg & accaggttgt & ctcctgcgac & ttcaacagca & actcccactc & 350 \\
\hline \multirow[t]{2}{*}{ rat } & G3PDH & 301 & tacactgagg & accaggttgt & ctcctgtgac & ttcaacagca & actcccattc & 350 \\
\hline & & & 360 & 370 & 380 & 390 & 400 & \\
\hline bovine & G3PDH & 351 & ttctaccttc & gatgctgggg & ctggcattgc & cctcaacgac & cactttgtca & 400 \\
\hline human & G3PDH & 351 & ctccaccttt & gacgctgggg & ctggcattgc & cctcaacgac & cactttgtca & 400 \\
\hline mouse & G3PDH & 351 & ttccaccttc & gatgccgggg & ctggcattgc & tctcaatgac & aactttgtca & 400 \\
\hline \multirow[t]{2}{*}{ rat } & G3PDH & & $\operatorname{acctt}$ & gatgctgggg & ctggcattgc & tctcaatgac & aactttgtga & 400 \\
\hline & & & 410 & 420 & 430 & 440 & 45 & \\
\hline bovine & G3PDH & 401 & agctcatttc & ctggtacgac & aatgaatttg & gctacagcaa & cagggtggt & \\
\hline human & G3PDH & 401 & agctcatttc & ctggtatgac & aacgaatttg & gctacagcaa & cagggtggtg & 45 \\
\hline mouse & G3PDH & 401 & agctcatttc & ctggtatgac & aatgaatacg & gctacagcaa & cagggtggtg & 450 \\
\hline \multirow[t]{2}{*}{ rat } & G3PDH & 401 & agctcatttc & ctggtatgac & aatgaatatg & gctacagcaa & cagggtggtg & 450 \\
\hline & & & 460 & 470 & 480 & 490 & 50 & \\
\hline bovine & G3PDH & 451 & ga..... & $\cdots \cdots$ & $\cdots \cdots$ & $\cdots \cdots \cdots$ & $\cdots \cdots$ & 500 \\
\hline hun & G3PDH & 45 & ga..... & $\cdots \cdots \cdots$ & $\cdots \cdots \cdots$ & $\cdots \cdots \cdots$ & $\cdots \cdots \cdots$ & 500 \\
\hline mous & G3PDH & 451 & ga...... & $\cdots \cdots \cdots$ & $\cdots \cdots \cdots$ & $\cdots \cdots \cdots$ & $\cdots \cdots \cdots$ & 500 \\
\hline rat & G3PDH & 451 & ga...... & $\cdots \cdots \cdots$ & $\cdots \cdots \cdots$ & $\cdots \cdots \cdots$ & $\cdots \cdots \cdots$ & 500 \\
\hline
\end{tabular}

Fig. 2. The nucleotide sequence of partial G3PDH cDNA from bovine ovarian tissue. The nucleotide sequence of RT-PCR products from bovine ovarian tissue was compared with nucleotide sequences of humans, mice and rats by using DNASIS software. The homology was $83.2 \%$. 


\begin{tabular}{|c|c|c|c|c|c|c|c|c|}
\hline & & & 10 & 20 & 30 & 40 & 50 & \\
\hline bovine & G3PDH & 1 & PPVHAITATQ & KTVDGPSGKL & WRDGRGAAQN & IIPASIGAAK & AVGKVIPELN & 50 \\
\hline human & G3PDH & 1 & PTVHAITATQ & KIVDGPSGKI & WRDGRGALON & ITPASTGAAK & AVGKVIPELD & 50 \\
\hline mouse & G3PDH & 1 & TIVHATTATO & KTVDGPSGKL & WRDGRGAAQN & TIPASTGAAK & AVGKVIPETN & 50 \\
\hline rat & G3PDH & 1 & TTVHAITATQ & KTVDGPSGKI & WRDGRGAAQN & IIPASTGAAK & AVGKVIPELN & 50 \\
\hline & & & 60 & 70 & 80 & 90 & 100 & \\
\hline bovine & G3PDH & 51 & GKUTGMAFRV & PTPNVSVYDI & TCRLEKPAKY & DEIKKVVKOA & SEGPIKGILG & 100 \\
\hline human & G3PDH & 51 & GKT TGMAFRV & PEANVSVODL & TCRLEKPAKY & DDIKKVVKQA & SEGPIKGILG & 100 \\
\hline mouse & G3PDH & 51 & GKITGMAFRV & PTPNUSVVDL & TCRLEKRAKY & DDTKKVVKOA & SEGPLKGILG & 100 \\
\hline rat & G3PDH & 51 & GKITGMAERV & PTPNVSVVDI & TCRLEKPARY & DDIKKVUKOA & AEGPIRGILG & 100 \\
\hline & & & 110 & 120 & 130 & 140 & 150 & \\
\hline bovine & G3PDH & 101 & YTEDQVUSCD & FNSDTHSSTE & DAGAGTATND & HEVKJISWYD & NEFGYSNRVV & 150 \\
\hline human & G3PDH & 101 & YTEHQVUSSD & FNSDTHSSTF & DAGAGTALND & HFVKI ISWYD & NEFGYSIRVV & 150 \\
\hline mouse & G3PDH & 101 & YTEDQVVSCD & FNSNSHSSTF & DAGAGIAIND & NEVRT ISWYD & NEYGYSNRVV & 150 \\
\hline rat & G3PDH & 101 & YTEDOVVSCD & BNSNSHSSTE & DAGAGIAIND & NEVKA ISWYD & NEYGYSNRVV & 150 \\
\hline
\end{tabular}

Fig. 3. Predicted amino acid sequence of partial G3PDH cDNA from bovine ovarian tissue. The predicted amino acid sequence of RT-PCR products from bovine ovarian tissue was compared with amino acid sequences of humans, mice and rats by using DNASIS software. The homology was $94.4 \%$.

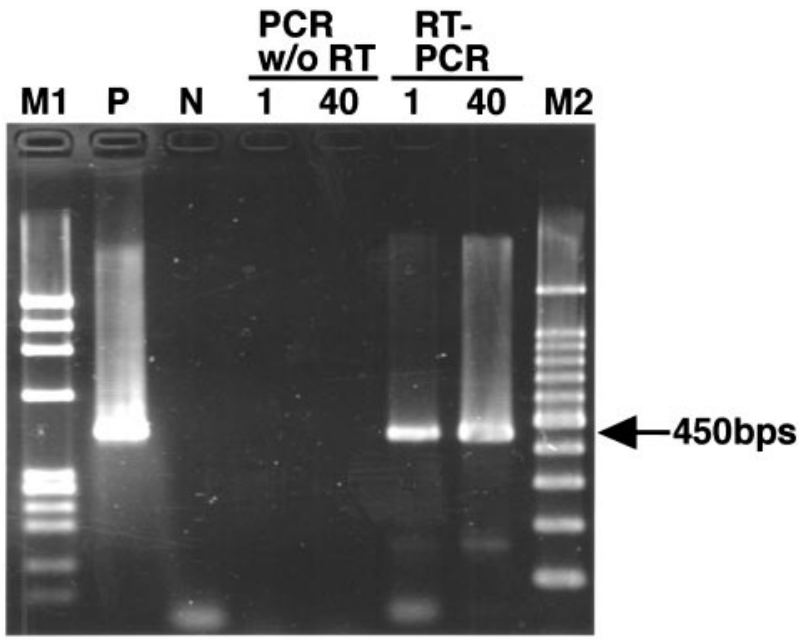

Fig. 4. Detection of G3PDH mRNA in single bovine oocytes. M1, molecular marker (øX174); P, positive control (bovine ovarian tissue); $\mathrm{N}$, negative control (distilled water); PCRw/oRT- 1, 40, PCR products made without the $\mathrm{RT}$ reaction from single and 40 oocytes, respectively; RT-PCR-1, 40, RT-PCR products from single and 40 oocytes, respectively; M2, molecular marker (100 bp DNA ladder). G3PDH mRNA was detected in both single and 40 oocytes.

acids were $94.4 \%$ identical with human (GenBank accession no. M17851), mouse (GenBank accession no. M32599) and rat (GenBank accession no. M17701) sequences. When the nucleotide sequence was compared to the other bovine sequences for G3PDH (GenBank accession nos. AJ000039 and U85042), a novel 7 nucleotide sequence was found. Therefore, based on the evidence, the cDNA fragments isolated in this study are partial cDNA coding bovine G3PDH.

\section{Expression of G3PDH mRNA in bovine oocytes and early embryos}

RT-PCR analysis with mRNA from bovine oocytes was performed to confirm G3PDH gene expression in single oocytes (Fig. 4). This indicated that it is possible to detect the gene expression of G3PDH in a single cell.

In the next experiments, expression of the G3PDH gene was evaluated in single bovine cells during oocyte maturation and embryo development. G3PDH messages were expressed in all stages of oocytes and embryos (Fig. 5). The G3PDH expression was, however, substantially weaker in embryos at 72 and $96 \mathrm{hpi}$, although it is difficult to precisely quantify the amount of RNA by RT-PCR. This observation suggests that transcriptional activity decreases between 72 and 96 hpi in early bovine embryogenesis.

\section{Discussion}

RT-PCR analysis is commonly used for detection of gene expression in mammalian oocytes or early embryos. When using the RT-PCR method the abundance of mRNA and its expression at all stages of development of oocytes/embryos is an important criterion in the selection of an endogenous control for gene expression.

In the first experiment we isolated and identified G3PDH cDNA clones from bovine ovarian tissue. Our results also indicated that the cDNA fragment is highly conserved in cattle, mice, rats and humans (Figs. 2 to 3). The high homology of the sequences may be due to the nature of G3PDH. In glycolysis, G3PDH reversibly catalyzes the oxidation and phosphorylation of D-glyceraldehyde 3-phosphate to 1,3-bisphosphoglycerate [7]. G3PDH is a tetrameric enzyme composed of chemically 


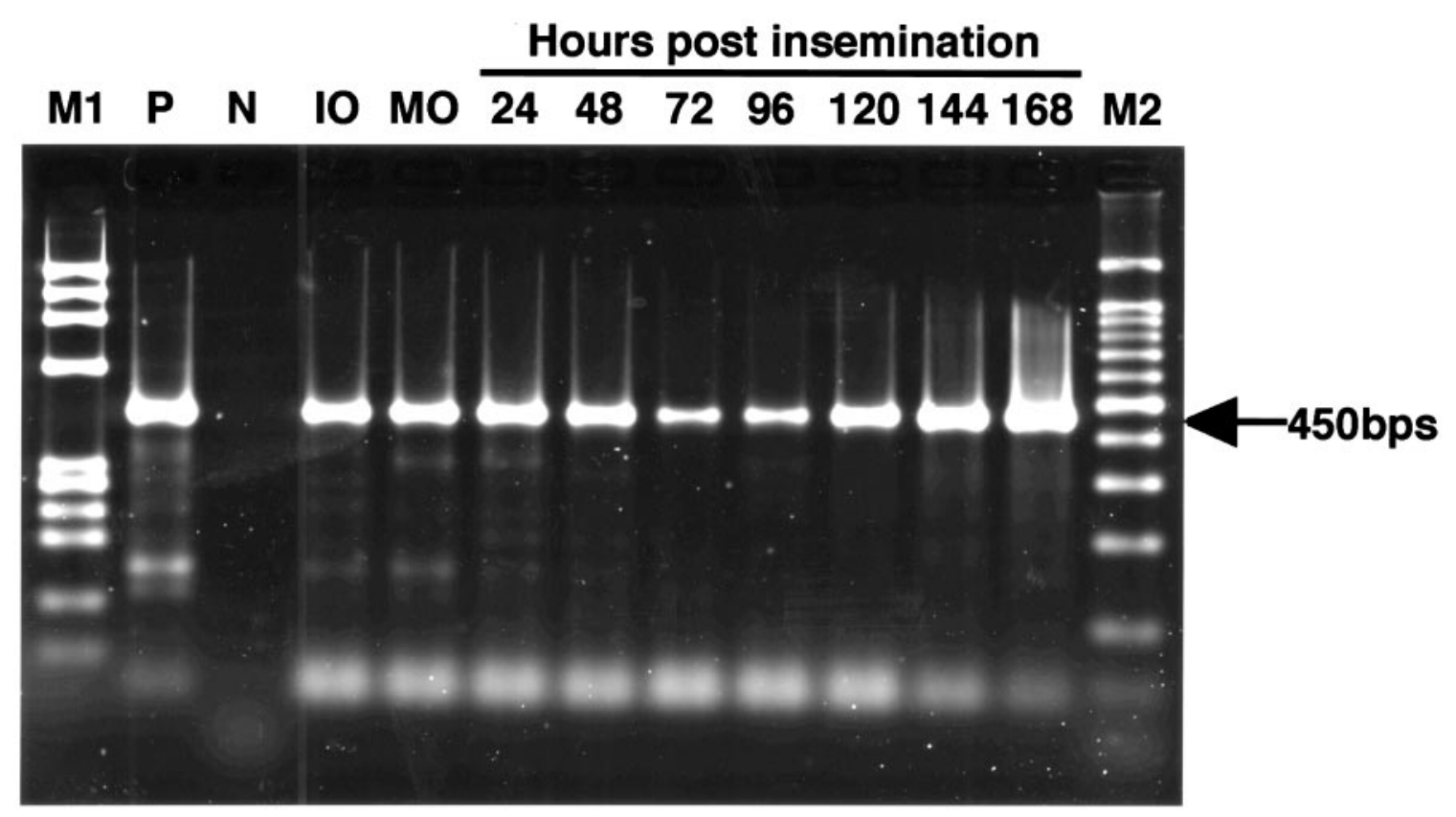

Fig. 5. Detection of G3PDH mRNA in single bovine oocytes and early embryos. M1, molecular marker (øX174); $\mathrm{P}$, positive control (bovine ovarian tissue); $\mathrm{N}$, negative control (distilled water); $\mathrm{IO}$, an immature oocyte; MO, a mature oocyte; Hours post insemination- 24 to 168, an embryo at 24, 48, 72, 96, 120, 144 and 168 hpi, respectively; M2, molecular marker (100 bp DNA ladder). G3PDH mRNA was detected in all single oocytes and embryos.

identical subunits and the amino acid sequence of the subunit has been determined in many kinds of animals and bacteria [3].

Many studies have been done on gene expression in oocytes and/or early embryos with RT-PCR [12-15], but usually several tens or hundreds of oocytes and/or embryos are used for extraction of total RNA. Recently it has been reported that RNA can be extracted from single bovine oocytes or embryos [16]. Our results indicate that mRNA including the G3PDH gene can be extracted from a single bovine oocyte (Fig. 4). This may be because our RNA extraction method is highly efficient and G3PDH mRNA is abundant in bovine oocytes. It is clear that there was no contamination of genomic DNA coding G3PDH in the mRNA extracts from oocytes in this study because no PCR product signals were detected when the reaction was done without the $\mathrm{RT}$ reaction (Fig. 4).

G3PDH mRNA was detected in immature and mature bovine oocytes and early embryos at the one-cell to blastocyst stages by RT-PCR analysis in this study (Fig. 5), but relatively weak signals were detected with embryos at 72 and 96 hpi. During the 8- to 16-cell stage in bovine embryos there is a major onset of embryonic gene transcription [18]; the main metabolic pathway after the 8- to 16-cell stage is glycolysis [17]. Because the embryo samples in this study at 72 and 96 hpi were at the 8- to 16-cell developmental stage, the weak signals may be due to the relatively low transcription activity of the G3PDH gene during this developmental stage.

In conclusion, G3PDH is suitable as an endogenous control for examining gene expression even with single bovine oocytes or early embryos by RT-PCR analysis.

\section{Acknowledgments}

We thank the staff of the Meat Inspection Office in Osaka City for providing the ovaries in this study. This study was supported in part by Molecular Bioengineering of Food Animal Protein Resources, Research for the Future Program, Japan Society for the Promotion of Science and by a Grant-in-Aid for Scientific Research (No. 10298937) from Japan's Ministry of Educatuion, Science and Culture.

\section{References}

1) Stark, R., Andre, C., Thierry, D., Cherel, M., Galibert, E. and Gluckman, E. (1993): The expression of 
cytokine and cytokine receptor genes in long-term bone marrow culture in congenital and acquired bone marrow hypoplasias. British J . Haematology, 83, 560566.

2) Foss, D.L., Baarsch, M.J . and Murtaugh, M.P. (1998): Regulation of hypoxanthine phosphoribosyltransferase, glyceraldehyde-3-phosphate dehydrogenase and $\beta$-actin mRNA expression in porcine immune cells and tissues. Anim. Biotech., 9, 67-78.

3) Suzuki, K. (1977): Glyceraldehyde-3-phosphate dehydrogenase. Protein Nucleic Acid and Enzyme, 22, 1614-1620.

4) Shonk, C.E., Majima, H., Kven B.J . and Boxer, G.E. (1966): Enzyme patterns in human tissues. IV. Comparison of glycolytic enzymes in surgical biopsies and autopsy specimens. Cancer Res., 26, 607-611.

5) Biragyn, A., Arkins, S. and Kelley, K.W. (1994): Riboprobe expression cassettes for measuring IGF-I, beta-actin and glyceral dehyde 3-phosphate dehydrogenase transcripts. J . Immunol. Methods, 168, 235244.

6) Piechaczyk, M., Blanchard, J .M., Marty, L., Dani, C., Panabieres, F., EI Sabouty, S., F ort, P. and J eanteur, P. (1984): Post-transcriptional regulation of glyceraldehyde-3-phosphate-dehydrogenase gene expression in rat tissues. Nucleic Acids Res., 12, 6951-6963.

7) MacLeod, A.R. (1981): Expression of the mRNA coding for glyceraldehyde-3-phosphate dehydrogenase. Eur. J. Biochem., 119, 353-358.

8) Saeki, K., Nagao, Y., Hoshi, M. and Kainuma, H. (1994): Effects of cumulus cells on sperm penetration of bovine oocytes in protein-free medium. Theriogenol ogy, 42, 1115-1123.

9) Saeki, K., Hoshi, M., Leibfried-Rutledge, M.L. and First, N.L. (1991): In vitro fertilization and development of bovine oocytes matured in serum-free medium. Biol. Reprod., 44, 256-260.

10) Takahashi, Y. and First, N.L. (1992): In vitro devel- opment of bovine one-cell embryos: Influence of glucose, lactate, pyruvate, amino acids and vitamins. Theriogenology, 37, 963-987.

11) Nagao, Y., Saeki, K., Hoshi, M. and Nagai, M. (1995): Early development of bovine embryos. J . Reprod. Dev., 41, 29-36.

12) Watson, A.J ., Hogan, A., Hahnel, A., Wiemer, K.E. and Schultz, G.A. (1992): Expression of growth factor ligand and receptor genes in the preimplantation bovine embryo. Mol. Reprod. Dev., 31, 87-95.

13) Gaudette, M.F. and Crain, W.R. (1991): A simple method for quantifying specific mRNAs in small number of early mouse embryos. Nucleic Acids Res., 19, 1879-1884.

14) Matsumoto, K., Anzai, M., Nakagata, N., Takahashi, A., Takahashi, Y. and Miyata, K. (1994): Onset of paternal gene activation in early mouse embryos fertilized with transgenic mouse sperm. Mol. Reprod. Dev., 39, 136- 140.

15) Nothias, J .Y., Miranda, M. and DePamphilis, M.L. (1996): Uncoupling of transcription and translation during zygotic gene activation in the mouse. EMBO J ., 15, 5715-5725.

16) Lequarre, A.S., Grisart, B., Moreau, B., Schuurbiers, N., Massip, A. and Dessy, F. (1997): Glucose metabolism during bovine preimplantation development: Analysis of gene expression in single oocytes and embryos. Mol. Reprod. Dev., 48, 216-226.

17) Thompson, J .G., Partridge, R.J ., Houghton, F.D., Cox, C.I . and Leese, H.J . (1996): Oxygen uptake and carbohydrate metabolism by in vitro derived bovine embryos. J . Reprod. Fertil., 106, 299-306.

18) Rieger, D., Loskutoff, N.M. and Betteridge, K.J . (1992): Developmentally related changes in the uptake and metabolism of glucose, glutamine and pyruvate by cattle embryos produced in vitro. Reprod. Fertil. Dev., 4, 547-557. 